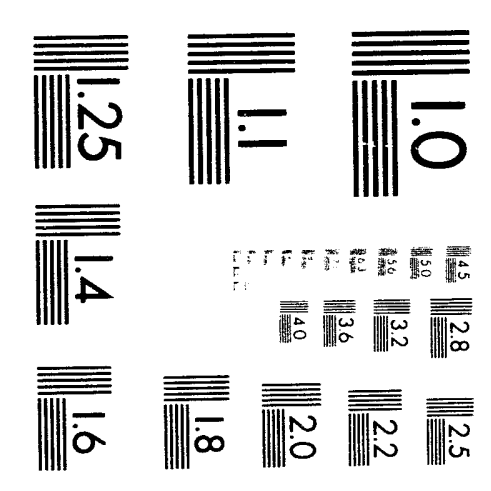



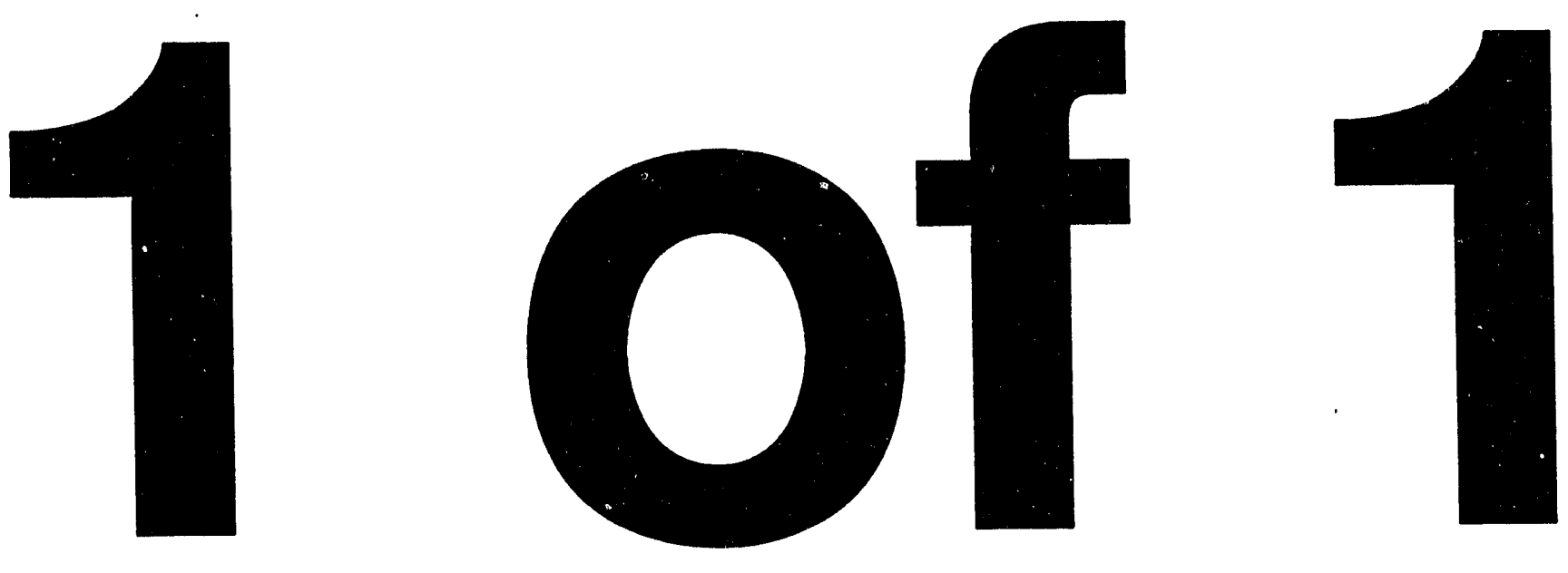


\section{PREDICTED FATE OF TRITIUM RESIDUUM FROM GROUNDWATER TRACER EXPERIMENTS IN THE AMARGOSA DESERT, SOUTHERN NEVADA}

by

Tom Brikowski

July 1993

Publication \#45103

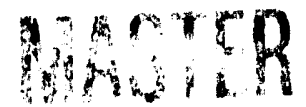

DISTRIBUTION OF THIS DOCUMENT IS UNLIMITEL 
This report was prepared as an account of work sponsored by the United States Government. Neither the United States nor the United States Department of Energy, nor any of their cmployecs, makes any warranty, express or implied, or assumes any legal liability or responsibility for the accuracy, completeness or uscfulness of any information, apparatus, product or process disclosed, or represents that its use would not infringe privately owned rights. Reference herein to any specific commercial product, process, or service by trade name, mark, manufacturer, or otherwisc, does not necessarily constitute or imply its endorsement, recommendation, or favoring by the United States Government or any agency thercof. The views and opinions of authors expressed herein do not necessarily state or reflect those of the United States Government or any agency thereof.

This report has becn reproduced directly from the best available copy.

Available to DOE and DOE contractors from the Office of Scientific and Technical Information, P.O. Box 62, Oak Ridge, TN 37831; prices available from (615) 576-8401.

Available to the public from the National Technical Information Service, U.S. Department of Commerce, 5285 Port Royall Rd., Springficld, VA 22161. 


\title{
PREDICTED FATE OF TRITIUM RESIDUUM FROM GROUNDWATER TRACER EXPERIMENTS IN THE AMARGOSA DESERT, SOUTHERN NEVADA
}

\author{
by \\ Tom Brikowski \\ Water Resources Center \\ Desert Research Institute \\ University and Community College System of Nevada \\ Reno, Nevada
}

Publication \#45103

prepared for

DOE Nevada Operations Office

U.S. Department of Energy

Las Vegas, Nevada

July 1993

The work upon which this report is based was supported by the U.S. Department of Energy under Contract 非DE-AC08-90NV10845. 


\section{CONTENTS}

ABSTRACT $\ldots \ldots \ldots \ldots \ldots \ldots \ldots \ldots \ldots \ldots \ldots \ldots \ldots \ldots \ldots \ldots \ldots \ldots \ldots$

INTRODUCTION $\ldots \ldots \ldots \ldots \ldots \ldots \ldots \ldots \ldots \ldots \ldots \ldots \ldots \ldots \ldots \ldots$

Tracer Test Description $\ldots \ldots \ldots \ldots \ldots \ldots \ldots \ldots \ldots \ldots \ldots \ldots \ldots \ldots$

MATHEMATICAL BASIS $\ldots \ldots \ldots \ldots \ldots \ldots \ldots \ldots \ldots \ldots \ldots \ldots \ldots$

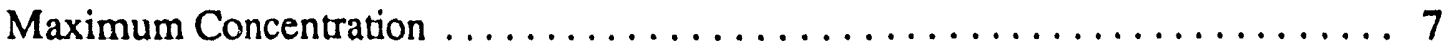

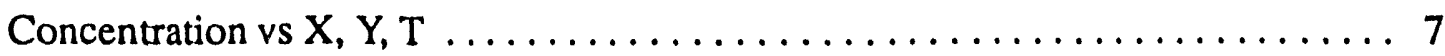

Effect of Parameter Uncertainty $\ldots \ldots \ldots \ldots \ldots \ldots \ldots \ldots \ldots \ldots \ldots$

APPLICATION AND RESULTS $\ldots \ldots \ldots \ldots \ldots \ldots \ldots \ldots \ldots \ldots \ldots \ldots$

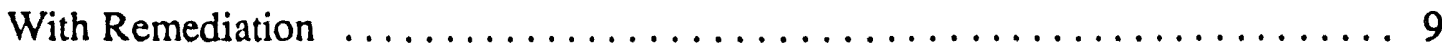

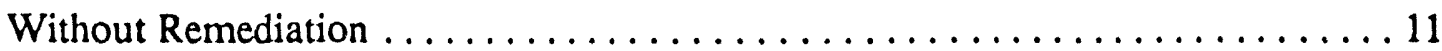

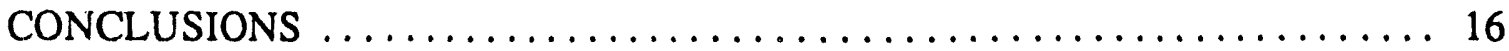

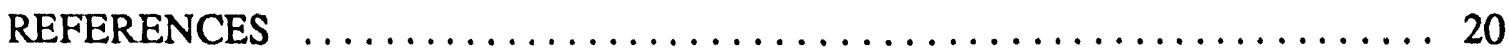

APPENDIX - Records of Site Remediation $\ldots \ldots \ldots \ldots \ldots \ldots \ldots \ldots \ldots$ 


\section{FIGURES}

1. Location of Amargosa Tracer Calibration Site (ATCS) and Nearby

Cultural Features and Springs. ........................... 2

2. Cross Section Along Regional Flow Direction at ATCS Showing

Stratigraphy and Well Construction. .......................... 3

3. Layout of the ATCS. ............................... 4

4. Breakthrough of Tracer at Hole TH-2, ATCS. .................. 6

5. Computed Peak Concentrations of Tritium vs Distance Downgradient from ATCS Using Inputs from Table 1 and $M_{o}=1.41 \mathrm{Ci}$ in eq. (1). ....... 10

6. Outlines of Computed Plume Boundaries vs Time for the ATCS,

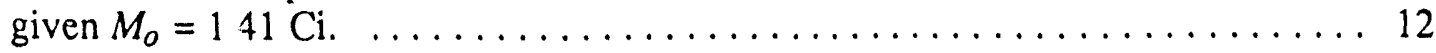

7. Outlines of Detectable Tritium vs Time for the ATCS, $M_{o}=1.4 \mathrm{Ci} \ldots \ldots \ldots 13$

8. Breakthrough Curve for Tritium at $X=14.2 \mathrm{~km}$, the Approximate Distance to the Nearest Springs from ATCS. .................. 14

9. Computed Peak Concentrations vs Distance Downgradient from ATCS Using Inputs from Table 1 and $M_{o}=14.1 \mathrm{Ci}$ in eq. (1)............. 15

10. Contributions to Variance of $C_{\max }$ for $M_{o}=14.1 \mathrm{Ci} \ldots \ldots \ldots \ldots \ldots \ldots$

11. Outlines of Computed Plume Boundaries vs Time for the ATCS,

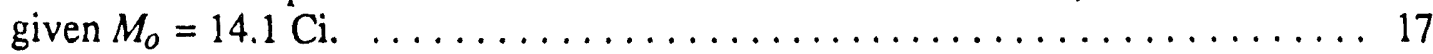

12. Outlines of Detectable Tritium vs Time for the ATCS Assuming $M_{o}=14.1 \mathrm{Ci}$.

\section{TABLES}

1. Input Parameters for Peak Concentration Calculation, ATCS Tritium Plume. . . . 9 


\begin{abstract}
Analytic solutions are used in this study to evaluate potential groundwater transport of tritium used in groundwater tracer tests southwest of the Nevada Test Site. Possible transport from this site is of interest because initial radionuclide concentrations were high (similar to those encountered after underground nuclear testing) and the site is close to groundwater discharge points $(12 \mathrm{~km})$. Anecdotal evidence indicates that 90 percent of these tracers were removed by pumping at the completion of the tests; this study examines the probable transport of the tracers with and without the removal. Classical dispersive transport analytic solutions are used, treating the tracer test as a point slug injection. Input parameters for the solutions were measured at the site, and consideration of parameter uncertainty is incorporated in the results.

With removal of the tracer, the maximum expected region with above-Safe Drinking Water Act (40 CFR 121) concentrations of tritium extends $5 \mathrm{~km}$ from the injection point, and does not reach any sites of public access. Detectable tritium from the tests is likely to have reached the Ash Meadows fault zone, but flow along the fault probably diluted the tracer to below detection limits before arrival at springs along the fault. Arrival at the springs would have occurred 20 to 25 years after the tests. Without removal of the tracer, the solutions indicate that tritium concentrations just above Safe Drinking Water Act standards would have reached the Ash Meadows fault zone. In this case, detectable tritium might have been found in Devil's Hole or Longstreet Spring, the nearest points of possible public exposure.
\end{abstract}




\section{INTRODUCTION}

The U.S. Geological Survey (USGS) Amargosa Tracer Calibration Site (ATCS, Figure 1) has been the location of three radioactive tracer tests within the Lower Carbonate Aquifer of southern Nevada. During 1971 and 1975, a total of 26.3 Curies (Ci) of tritium was injected into the aquifer in these tests, as well as an unspecified amount of sulfur-35 $\left({ }^{35} \mathrm{~S}\right)$. While records of the releases are readily available (Claassen and Cordes, 1975; Leap, 1992) records of the ultimate disposition of the tracers are currently unknown. Recent concerns about groundwater impacts of NTS activities on downgradient wells and springs have raised the issue of the long-term impact of the tracer tests at ATCS. Groundwater leaving the southern NTS boundary passes beneath ATCS before arriving at springs in Ash Meadows; therefore, activities at ATCS would be expected to impact spring water quality before any on-NTS activity might do so.

Fortunately, much of the radioactive tracer was apparently removed from the aquifer by pumping after each test and evaporated from an unlined surface pond (Claassen, personal comm., 1993; Leap, personal comm., 1993). To date, no official records of that remediation have been found, leaving the potential impacts of ATCS open to debate. This study evaluates the potential for downgradient water quality effects with and without the removal of 90 percent of the tracer at the source. Relatively simple analytic solutions are used to make a "reconnaissance" assessment of tritium migration from ATCS. The solutions indicate that in either case detectable concentrations of tritium (but well below the Safe Drinking Water Act standard of 20,000 pico-Curies per liter, $\mathrm{pCi} / 1$ ) might migrate to downgradient springs. Considerable dilution is likely to take place near the springs and, therefore, observation of ATCS tritium at the springs is highly unlikely unless all injected tracer remained in the carbonate aquifer at ATCS (no removal).

\section{Tracer Test Description}

The 1971 tracer test at ATCS was designed to measure the dynamic dispersivity of the carbonate aquifer at the site using the two-well recirculating tracer method of Grove and Beetem (1971). In this technique, a pair of wells, one pumping from the aquifer and the other injecting the water from the first, are used to establish a steady-state elliptical zone of known groundwater velocity between the wells. An "instantaneous" slug of tracer is injected into the system and concentration (breakthrough) at the pumping well is monitored. To obtain dispersivity from these measurements, the system is viewed as a collection of arcuate longitudinal dispersion columns, and synthetic breakthrough curves are generated for various combinations of dispersivity and effective porosity. Fitting the observed breakthrough curve to these synthetic curves allows determination of the apparent longitudinal dispersivity and effective porosity of the aquifer.

Five wells were installed at the site, four of them extending through the alluvium to the confined carbonate aquifer below (Figure 2). Two of these wells oriented along the regional flow direction were used as the recirculating pair; concentrations were monitored in two wells oriented perpendicular to the regional flow direction, midway between the recirculating pair (Figure 3). The carbonate aquifer beneath ATCS is composed of fractured Cambrian dolomite of the Bonanza King formation underlain by limestone of the Carrara formation (Johnston, 1968). Both units are a part of the Lower Carbonate Aquifer defined by Winograd and 


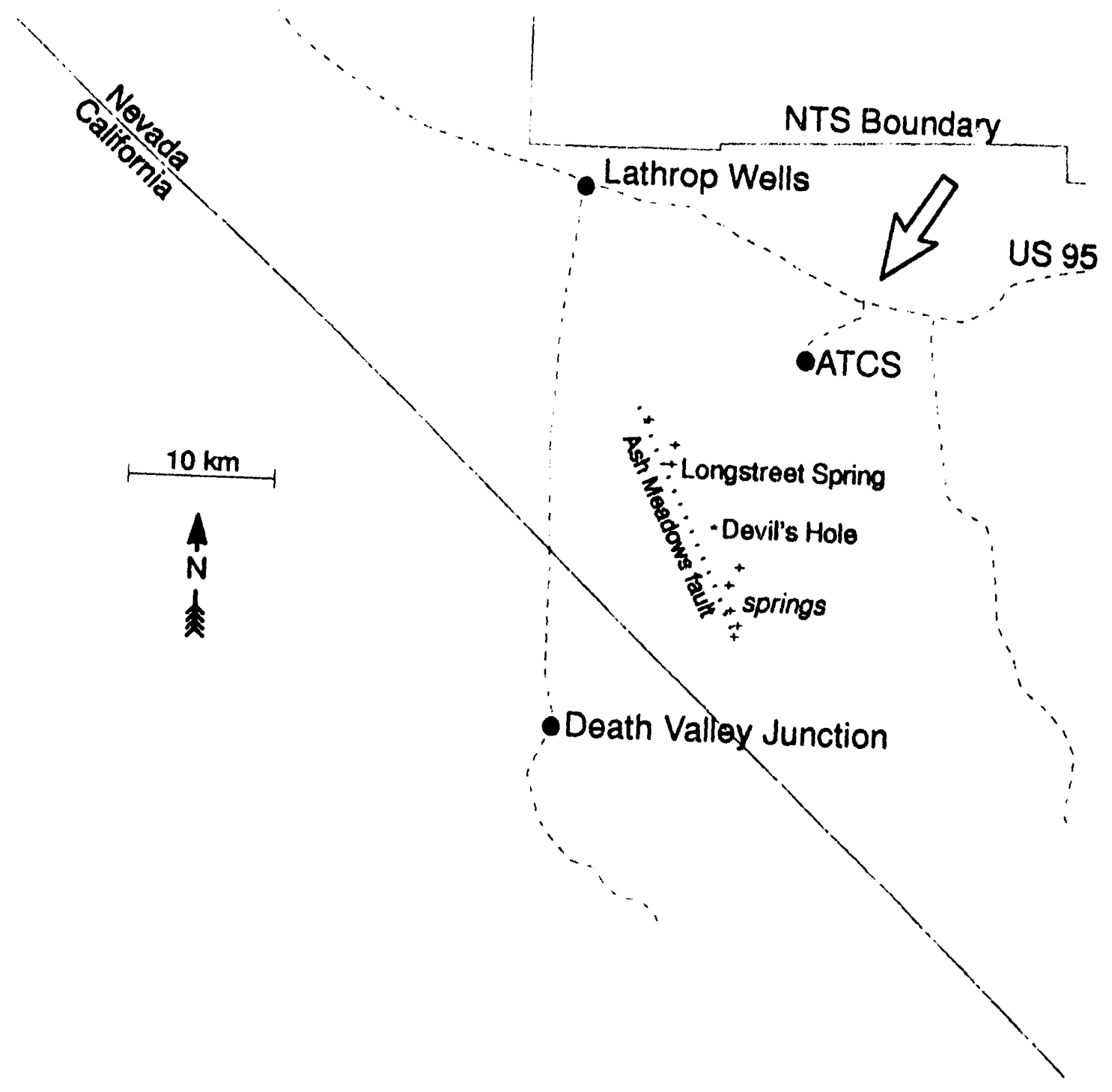

Figure 1. Location of Amargosa Tracer Calibration Site (ATCS) and Nearby Cultural Features and Springs. Regional groundwater flow is indicated by large arrow and "+" indicates location of a spring. Highways shown by dashed line and approximate location of Ash Meadows fault shown by dotted line (after Winograd and Thordarson, 1975). 


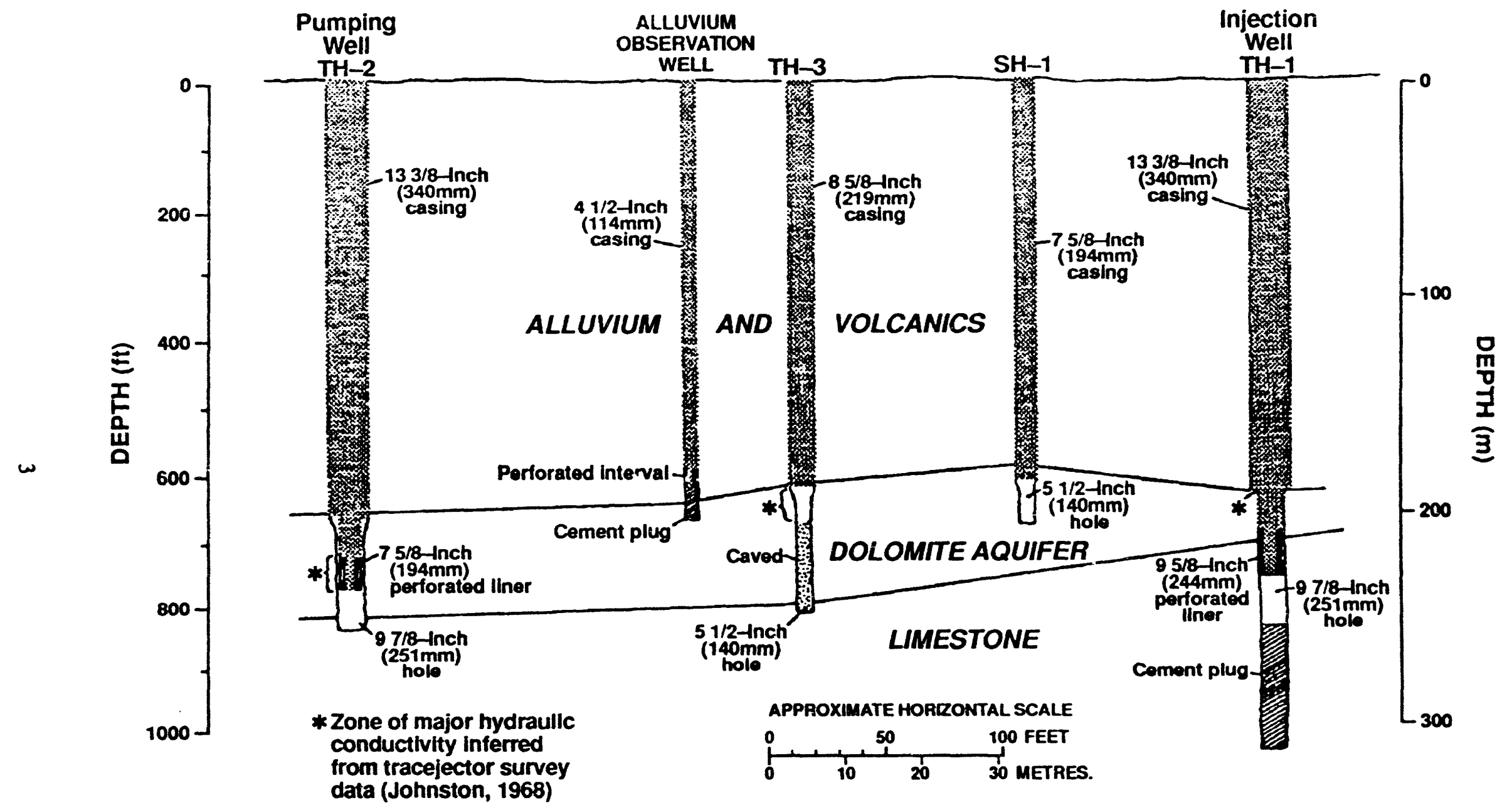

Figure 2. Cross Section Along Regional Flow Direction at ATCS Showing Stratigraphy and Well Construction (after Claassen and Cordes, 1975). 


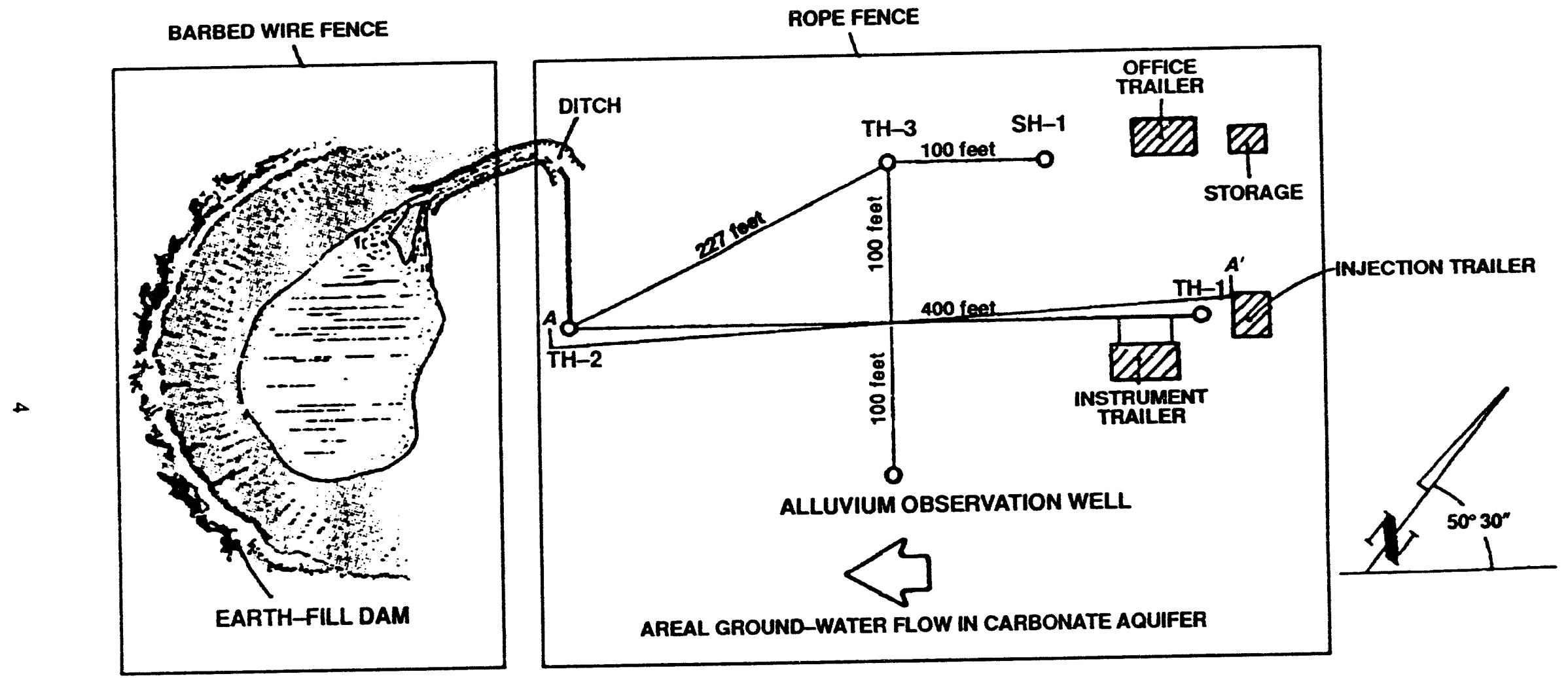

Figure 3. Layout of the ATCS (after Claassen and Cordes, 1975). 
Thordarson (1975). Transmissivities in this unit are relatively high compared to other aquifers in the area, ranging from 4,400 to $9,900 \mathrm{~m}^{2} / \mathrm{d}$; permeable zones are associated with secondarily enlarged fractures in the rock. Permeability decreases with depth at this site, and the top $50 \mathrm{~m}$ of carbonate are considered to be the permeable zone. Single-well tracer tests conducted prior to 1971 yielded independent estimates of the product of effective porosity and aquifer thickness (Leap, 1992).

Each tracer test began after one month of pumping, intended to establish a steady-state flow field. In July 1971, a slug of tritium (14.141 Ci) was injected as a constant-concentration pulse in well TH-1, then breakthrough monitored for 30 days in the pumping well (TH-2 in Figure 2). The breakthrough curve shows a classic skewed peak, with many large-magnitude spikes superimposed on it (Figure 4). Measured values at this well ranged from $10^{4}$ to $10^{6} \mathrm{pCi} /$, the spikes attributed to rapid transport in fractures. At the end of 30 days, concentrations in the recirculating system had stabilized at approximate $y^{\prime} 2 \times 10^{-4}$ of original concentrations, or 145.3 $\mathrm{pCi} / 1$. Mass-balance calculations suggest that more than 90 percent of the injected tritium remained within the recirculating system. Based on these values, a volume of $9.73 \times 10^{4} \mathrm{~m}^{3}$ of water contained this tritium at the end of the tracer test. Given the computed value of $\phi b=0.88$ $m$ (porosity-thickness product) the area of aquifer containing tritium at the end of the test was $1.11 \times 10^{5} \mathrm{~m}^{2}$, equivalent to a circle of an approximate radius of $200 \mathrm{~m}$. The dispersivity estimated from this tracer test was $15 \mathrm{~m}$.

Two subsequent tests were carried out, including a second test evaluating ${ }^{35} \mathrm{~S}$ as the tracer (Leap and Belmonte, 1992). This test ran for 38 days, finding an apparent dispersivity of $22.9 \mathrm{~m}$ and a porosity-aquifer thickness product of $0.84 \mathrm{~m}$. A third test was carried out in 1975 using tritium and bromine $(\mathrm{Br})$ simultaneously (Leap and Belmonte, 1992). It was designed to mimic the first test as closely as possible to compare the performance of the two tracers. In this test, 12.2 $\mathrm{Ci}$ of tritium were injected, and a dispersivity of $27.4 \mathrm{~m}$ and porosity-thickness product of 0.84 was found for the tritium, $30.5 \mathrm{~m}$ and 0.84 , respectively, for Br. Leap and Belmonte (1992) speculate that the differences in estimated dispersivity result from differing pumping rates which, in turn, affected fracture apertures and pore velocity distributions. An alternative hypothesis is that test-related reduction in hydraulic conductivity near the injection well reflected clogging of fine fractures, resulting in increased dispersion during the test.

\section{MATHEMATICAL BASIS}

The goal of this study is to make a rapid assessment of the potential migration of these radioactive tracers, including the effects of parameter uncertainty. This kind of prediction is most readily made using analytic solutions. The analytic solution approach requires a highly simplified view of the hydrologic system, but allows for straightforward evaluation of parameter uncertainty. Two types of prediction are desired, estimates of maximum probable concentrations as a function of position, and estimates of the evolution of the plume with time (plume outline). To provide these results, two different formulas will be employed below. Both assume injection of a slug of contaminant at a point in uniform flow, where the duration of injection is short compared to the total time of movement of the plume; consequently, the solutions do not consider the effects of dilution during the recirculating tests at ATCS. Since both solutions are based on the mass of tracer, not its initial distribution, they will be accurate at sufficient distances from the point of injection (e.g., $\gtrsim 1 \mathrm{~km}$ ). 
SAMPLE CONCENTRATION (C) INJECTED TRACER CONCENTRATION $\left(\mathrm{C}_{0}\right)$

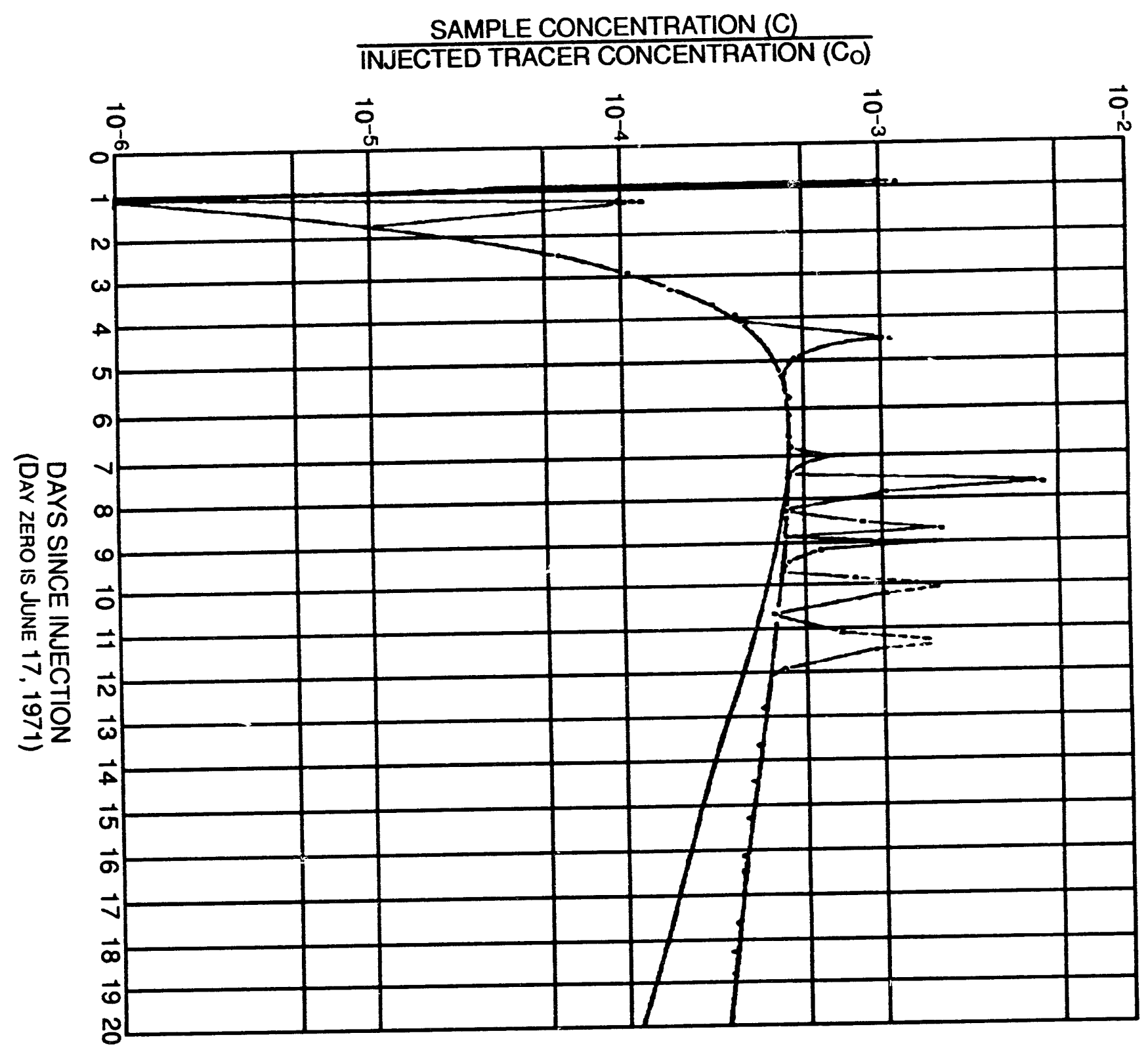




\section{Maximum Concentration}

Sauty (1980) presents solutions to the two-dimensional advection-dispersion equation for slug injection into a uniform flow. The following relations describe the maximum concentration $C_{\max }$ that will be experienced at any point $\left(x_{n} y_{r}\right)$ in the aquifer:

$$
\begin{aligned}
C_{\max }\left(x_{r} y_{r}\right) & =\frac{m /(\phi b)}{4 \pi a_{L} \sqrt{a_{L} a_{T} x_{r} t_{r \max }}} \cdot \exp \left(-\frac{x_{r}}{4} \frac{\left(1-t_{r \max }\right)^{2}}{t_{r \max }}-\frac{y_{r}^{2}}{4 x_{r} t_{r \max }}\right) \\
t_{r \max } & =\sqrt{1+\left(\frac{2}{x_{r}}\right)^{2}+\left(\frac{y_{r}}{x_{r}}\right)^{2}}-\frac{2}{x_{r}} \\
x_{r} & =\frac{x}{a_{L}} \\
y_{r} & =\frac{y}{\sqrt{a_{L} a_{T}}}
\end{aligned}
$$

where $\alpha_{L}$ and $\alpha_{T}$ are the longitudinal and transverse dispersivities, $m$ the solute mass injected, $\phi$ the effective porosity, and $b$ is the aquifer thickness. The effect of radioactive decay can be included by modifying $C_{\max }$ as follows:

$$
C_{\max \text { decay }} \approx C_{\max } e^{-\lambda \frac{x}{x}}
$$

where $\lambda$ is the decay constant, $u$ is the magnitude of the uniform flow. The relation is indicated as approximate, since no consideration is made of the time required for movement of species away from the uniform velocity direction. As such, the relation above should slightly overestimate concentrations away from the principal axis of the plume.

\section{Concentration vs $\mathbf{X}, \mathbf{Y}, \mathbf{T}$}

The body of contaminated water will form an ellipse, which grows then shrinks with time, moving steadily downgradient. The form of this plume with time can be calculated utilizing a solution derived by De Josselin de Jong (1958), as described in Fried and Combarnous (1971, p. 229). These authors give the concentration as a function of location and time:

$$
\begin{aligned}
C(x, y, t) & =\frac{C_{o} V_{o}}{4 \pi t \sqrt{a_{L} a_{T}}} \exp \left\{-\frac{\left[x-\left(x_{o}+u t\right)\right]^{2}}{4 a_{L^{t}}}-\frac{\left(y-y_{o}\right)^{2}}{4 a_{T^{t}}}\right\} \\
& =\frac{M_{o}}{4 \pi \phi b t \sqrt{a_{L} a_{T}}} \exp \left\{-\frac{\left[x-\left(x_{o}+u t\right)\right]^{2}}{4 a_{L} t}-\frac{\left(y-y_{o}\right)^{2}}{4 a_{T^{t}}}\right\}
\end{aligned}
$$

where $C_{o}$ is the concentration of the injectate, $V_{o}$ is the injected volume, $M_{o}$ is the mass of tracer injected, $\left(x_{0}, y_{0}\right)$ is the point of injection, and $u$ is the pore velocity (uniform). Equation (3) is a slightly more convenient form of the original solution. Tritium concentrations computed using this formula can be corrected for radioactive decay by multiplying by $e^{-\frac{\lambda x}{r}}$. 


\section{Effect of Parameter Uncertainty}

Analytic solutions are formulated assuming complete knowledge of input parameter values. For applications where parameters are uncertain, but where first and second statistical moments are known (expected value or mean and variance) the first two moments of the final solution can be estimated. In general terms, for an algebraic function $g$ of $N$ uncorrelated random variables $X$ :

$$
\begin{aligned}
m\left[g\left(X_{1} \ldots X_{N}\right)\right] & \approx g\left(m_{X_{1}} \ldots m_{X_{N}}\right)+\frac{1}{2} \sum_{i=1}^{N} \frac{\partial^{2} g}{\partial X_{i}^{2}} \mid \cdot \operatorname{Var}\left[X_{i}\right] \\
\operatorname{Var}\left[g\left(X_{1} \ldots X_{N}\right)\right] & \left.\approx \sum_{i=1}^{N}\left(\frac{\partial g}{\partial X_{i}}\right)^{2}\right|_{h_{X}} \cdot \operatorname{Var}\left[X_{i}\right]
\end{aligned}
$$

where $m[\cdot]$ is the expected (mean) value, and $\operatorname{Var}[\cdot]$ is the variance (Benjamin and Cornell, 1970, p. 184). The expressions on the right are Taylor's Series approximations, truncated after the third and second terms, respectively. Higher order terms are functions of higher order statistical moments of the parameters. The partial derivatives in eqs. (4) and (5) are evaluated using the mean values of the parameters $X_{i}$.

\section{APPLICATION AND RESULTS}

Of several documented releases of radioactivity to groundwater related to NTS activities, the ATCS tracer tests are the nearest to the accessible environment. Basic concerns about this site are the potential for public hazard, and the potential for detectable (but harmless) changes in downgradient groundwater quality. In this study, the first concern will be addressed by assuming that hazard can be defined as above-Safe Drinking Water Act standard concentrations $(20,000 \mathrm{pCi} / 1)$ of tritium. Estimating the area underlain by such concentrations will indicate the potential for public exposure. The second concern will be addressed by estimating the distribution of above-present-day precipitation concentrations of tritium, taken to be $50 \mathrm{pCi} / \mathrm{l}$ (15 tritium units, TU). The potential for surface discharge of such concentrations originating from the ATCS will be evaluated since this discharge might be mistakenly identified as originating from weapons testing on the NTS.

The closest points of accessible environment to ATCS are springs along the Ash Meadows fault. These are Longstreet and School springs, and Devil's Hole (Figure 1). Longstreet Spring and Devil's Hole lie $5 \mathrm{~km}$ apart along the fault. Groundwater passing beneath ATCS is expected to move uniformly west-southwest until it encounters the Ash Meadows fault (Winograd and Thordarson, 1975; Dudley and Larson, 1976) about mid-way between Longstreet Spring and Devil's Hole. Then groundwater is expected to move along the fault either northwest or southeast to discharging springs. Since the solutions used in this study assume a constant groundwater flow direction, movement along the fault must be treated as a "bend-in-section," i.e., uniform flow up to the fault, then uniform flow along the fault. A significant amount of dilution probably takes place along the fault as it collects groundwater from the west-southwest uniform flow. This process is not considered here, and for portions of the flow path that lie beyond the intersection of the flow path and fault (i.e., distances $>11 \mathrm{~km}$ ), the results below represent maximum possible values. 
Inputs for the solutions are generally taken from measurements at the ATCS site (Table 1). Claassen and Cordes (1975) report five measurements of aquifer thickness-effective porosity product $\phi b$, allowing a mean and variance to be computed. Variance in longitudinal dispersivity $a_{L}$ was determined from ATCS measurements and estimated changes in the parameter with transport distance. Transverse dispersivity was estimated from empirical ratios of $\frac{a_{L}}{a_{T}}$ (Fetter, 1993). Uniform flow pore velocity and direction was determined from regional gradient estimates and local measurements of transmissivity and porosity (Claassen and Cordes, 1975; Leap, 1992).

Since no official records of ATCS remediation have been found, the mass of tracer left in the aquifer after tracer testing must be considered uncertain. Two scenarios will be considered, the most likely case that only 10 percent of the original tracer mass remained in the aquifer at the end of each test, and a second assuming the remediation did not take place, leaving the full mass of tracer in the aquifer.

\section{With Remediation}

The 1971 tracer test, in which $14.14 \mathrm{Ci}$ of tritium was injected, will be modeled here. Measurements during removal of the tracer from the aquifer indicate that 90 percent of the original tritium was pumped into the surface pond; therefore, the mass of tritium remaining in the aquifer would have been approximately $1.41 \mathrm{Ci}$. Transport of this mass is evaluated in this section. The second test, carried out in 1975 with $12.6 \mathrm{Ci}$ of tritium, (Leap, 1992) is not modeled, but would yield similar results delayed by 4 years.

Concentration vs distance directly downgradient from ATCS can be computed by taking $y=0$ in eq. (1) (decay included using eqs. 1 through 5). The expected value of maximum concentration can be determined by applying eq. (4) to this formula. Equation (5) can be used to determine the standard deviation $(\sigma)$ of computed $C_{\max }$, and from that a 95 percent confidence interval $(2 \sigma)$ estimated. Carrying out this computation indicates that the area underlain by greater than $20,000 \mathrm{pCi} / \mathrm{l}$ tritium extends no more than $5 \mathrm{~km}$ downgradient from ATCS (with 95 percent confidence; Figure 5). The most probable plume length is just over $2 \mathrm{~km}$ (solid line on Figure 5). Detectable tritium concentrations would be expected up to $20 \mathrm{~km}$ down the flow path,

TABLE 1. INPUT PARAMETERS FOR PEAK CONCENTRATION CALCULATION, ATCS TRITIUM PLUME.

\begin{tabular}{lccc}
\hline Parameter & Expected Value & Variance & Units \\
\hline$\phi b$ - aquifer thickness-effective & & & \\
porosity product & 0.608 & 0.0731 & $\mathrm{~m}$ \\
$M_{O}$ - injected mass & 1.4141 & - & $\mathrm{Ci}$ \\
$\alpha_{L}-$ longitudinal dispersivity & 15.0 & 44.44 & $\mathrm{~m}$ \\
$\alpha_{T}-$ transverse dispersivity & 1.5 & 0.0851 & $\mathrm{~m}$ \\
$\lambda-$ tritium decay constant & $1.55 \times 10^{-4}$ & - & $1 /$ day \\
$u-$ groundwater pore velocity & 1.77 & 0.2952 & $\mathrm{~m} / \mathrm{day}$ \\
\hline
\end{tabular}




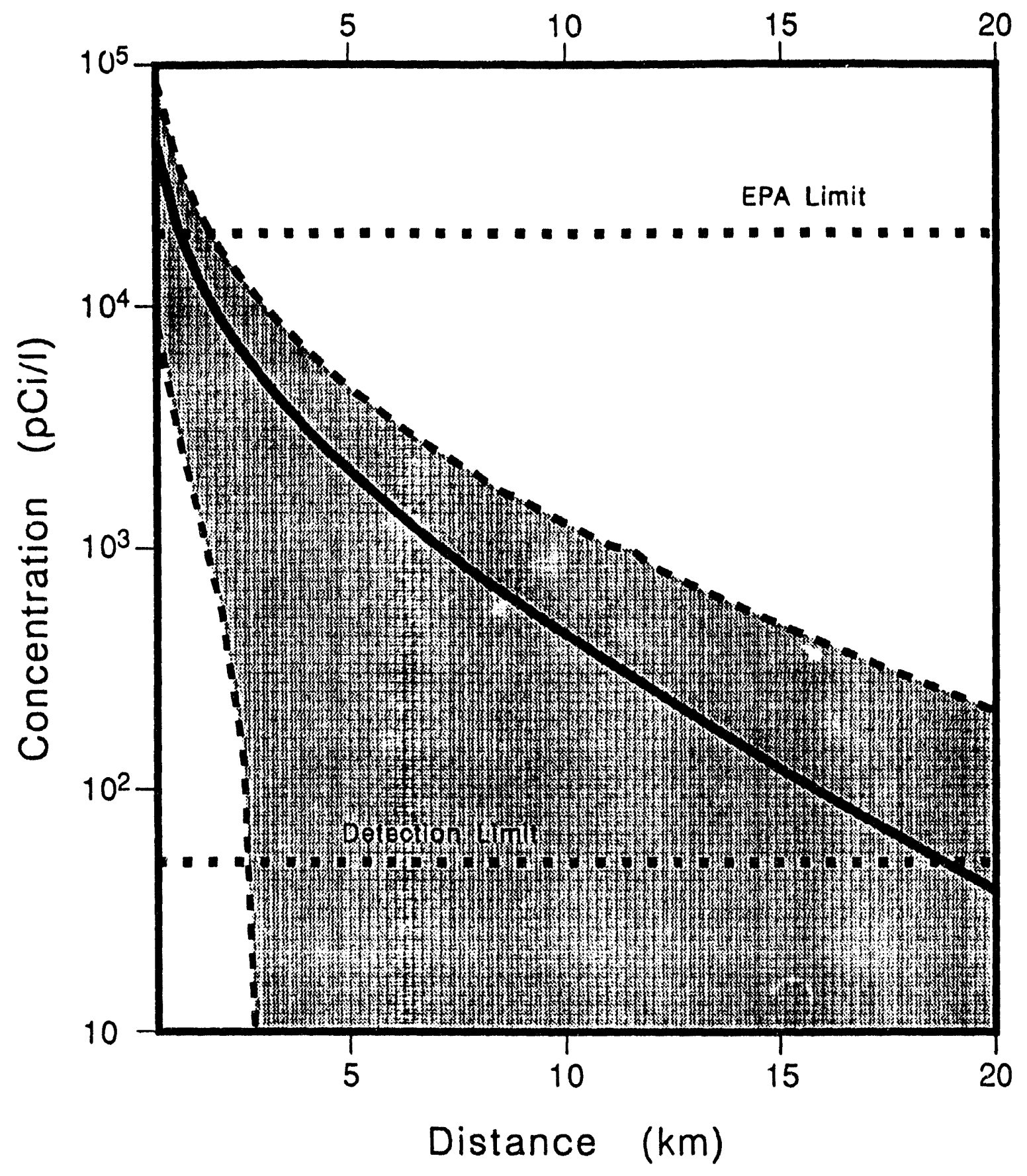

Figure 5. Computed Peak Concentrations of Tritium vs Distance Downgradient from ATCS Using Inputs from Table 1 and $M_{o}=1.41 \mathrm{Ci}$ in eq. (1). Solid line shows expected value of $C_{\max }, 95 \%$ confidence interval $(2 \sigma)$ value shown by shaded region. 
neglecting dilution along the Ash Meadows fault. A 95 percent probability is indicated that the downgradient extent of detectable tritium is less than $30 \mathrm{~km}$.

The dimensions of the tritium plume at various times can be computed using eq. (3). A maximum extent of tritium exceeding threshold values can be determined using eqs. (4) and (5) applied to eq. (1). The area expected to experience above $20,000 \mathrm{pCi} /$ concentrations (with a 95 percent confidence) is narrow (Figure 6) and as in Figure 5, extends approximately $5 \mathrm{~km}$ downgradient. Outlines of the area containing above $20,000 \mathrm{pCi} / 1$ concentrations ("plumes") are illustrated for one and two years, forming elliptical shapes that shrink steadily downgradient as a consequence of dispersion. No known access to the Lower Carbonate Aquifer (boreholes or springs, except ATCS) is present within the 95 percent confidence area illustrated in Figure 6; therefore, the models used here indicate no public hazard (as defined above) from the remediated ATCS tests.

The second concern at ATCS is whether the remaining tracer could be detectable in downgradient springs. Calculations of maximum probable concentrations directly downgradient indicate that levels above detection limit could reach as far as the neaisst springs (a distance of $14.2 \mathrm{~km}$; Figure 6). The areal extent of abc se-detection-limit waters can be illustrated as above, and estimates of plurne dimensions at selected times indicated. Contours of $50 \mathrm{pCi} / 1$ expand as the plume moves downgradient as a result of the predominance of dispersion over radioactive decay effects (Figure 7). The ellipses begin to shrink beyond $20 \mathrm{~km}$ travel distance (not shown). Since uniform flow is interrupted at the Ash Meadows fault, a rough idea of the extent of detectable tritium can be gained by imagining the 20-year plume "bent" at the fault line and extending along it in either direction.

A breakthrough curve can be calculated for specific points. The closest springs lie $14.2 \mathrm{~km}$ along the flow path from A'TCS. Equation (3) can be used to determine the breakthrough curve for tritium at that distance (Figure 8). This curve shows first arrival at the distance of the nearest springs at 19 years, and disappearance of detectable tritium at 24 years. A symmetric breakthrough curve is calculated since eq. (3) does not consider kinetic effects and the problem is characterized by large Peclet number ( $\approx \frac{u t}{a}$; Sauty, 1980).

\section{Without Remediation}

The lack of accessible records describing the removal of tracers at the end of testing at ATCS can be treated as an uncertainty about the initial contaminant mass in the calculations above. Although highly improbable, transport in the Lower Carbonate Aquifer of the entire initial tracer mass cannot be ruled out at present; consequently, predictions of transport using the initial tracer mass $(14.141 \mathrm{Ci}, 1971$ test) were made to assess the probability of hazardous or detectable tritium levels in the accessible environment given this scenario. As above, maximum expected concentrations directly downgradient can be computed using eq. (1). For an initial mass of $14.1 \mathrm{Ci}$, this calculation indicates that concentrations above $20,000 \mathrm{pCi} / \mathrm{h}$ are expected to $11 \mathrm{~km}$ down-hydraulic-gradient (Figure 9). The results indicate a 95 percent probability that the extent of above $20,000 \mathrm{pCi} / /$ concentrations will be less than $16 \mathrm{~km}$ along the flow path. The expected value of $C_{\max }$ at the approximate distance to the springs is $9,020 \mathrm{pCi} /$ with a $\sigma$ of 6,840 $\mathrm{pCi} / 1$; ignoring dilution along the fault zone, these values indicate a probability of 73 percent that 
$1 \mathrm{~km}$

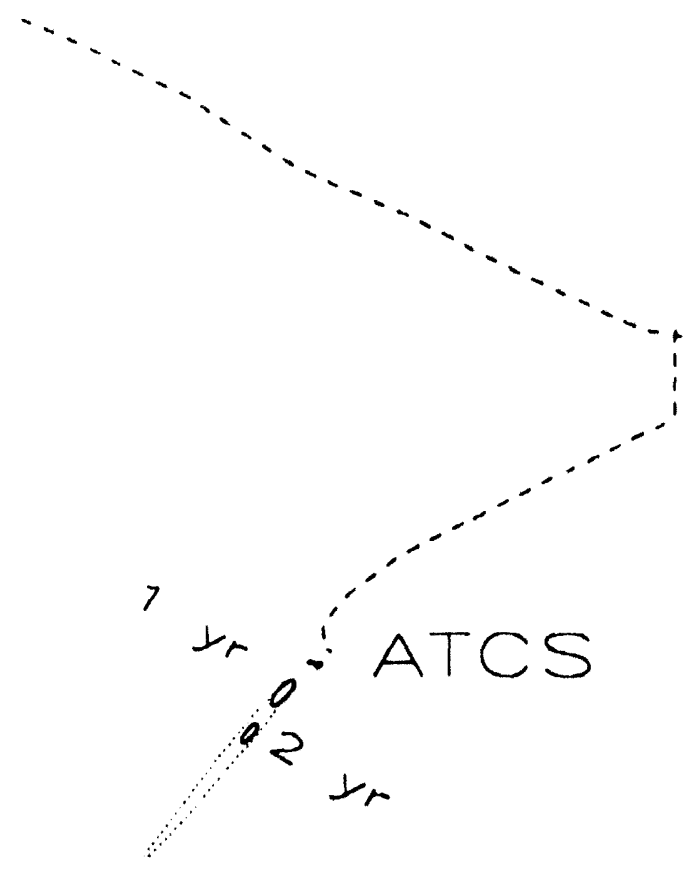

springs

Figure 6. Outlines of Computed Plume Boundaries vs Time for the ATCS, given $M_{0}=1.41 \mathrm{Ci}$. Ellipses show the areas predicted to exceed $20,000 \mathrm{pCi} /$ tritium at the indicated times. Dotted line represents $95 \%$ confidence region for above $20,000 \mathrm{pCi} /$ concentrations. 


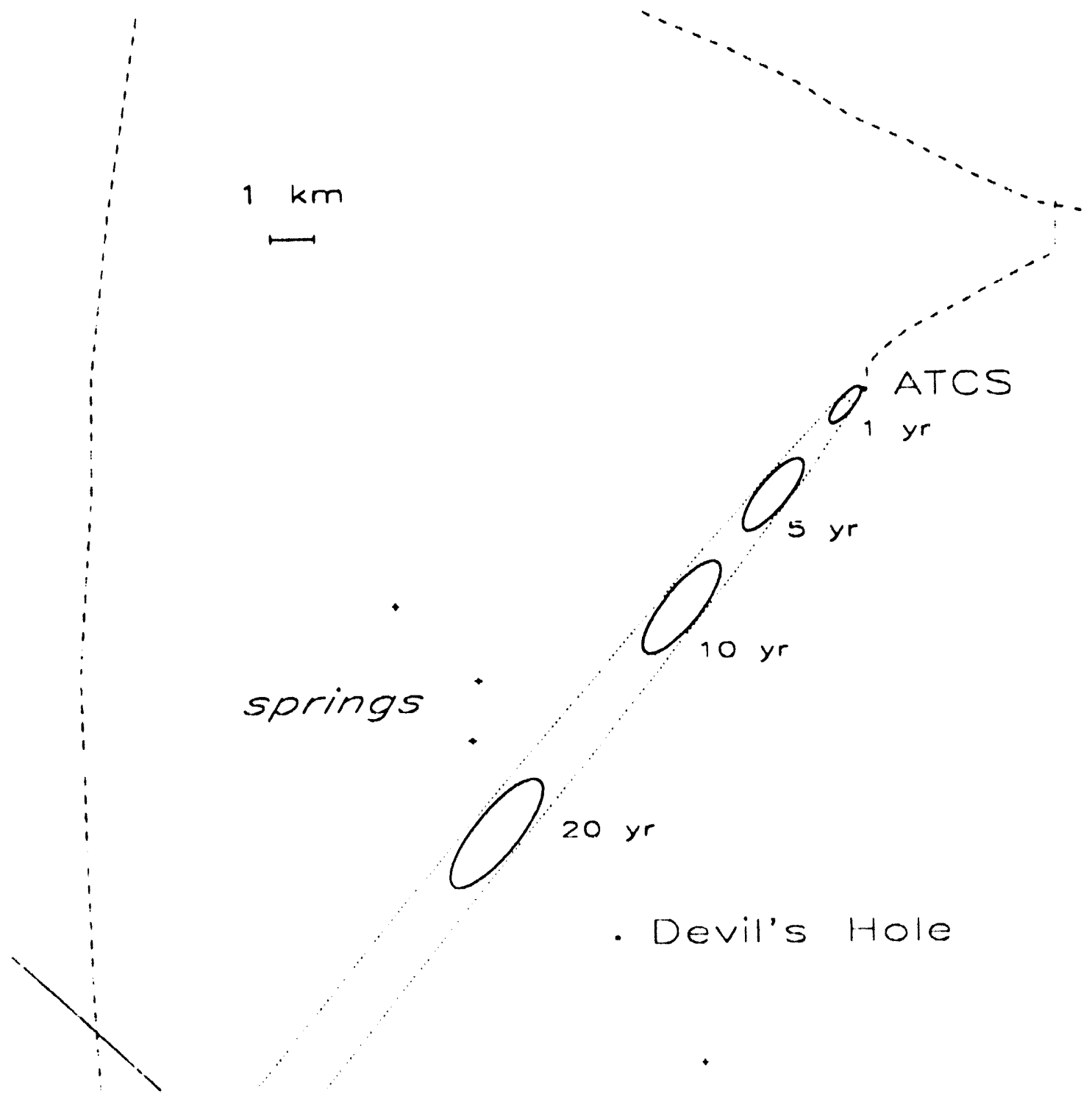

Figure 7. Outlines of Detectable Tritium vs Time for the ATCS, $M_{0}=1.4 \mathrm{Ci}$. Contour of the $50 \mathrm{pCi} /$ concentration is shown, equivalent to levels of tritium in 1990 precipitation in the area. Dotted line represents $95 \%$ confidence region for concentrations exceeding $50 \mathrm{pCi} / 1$. 


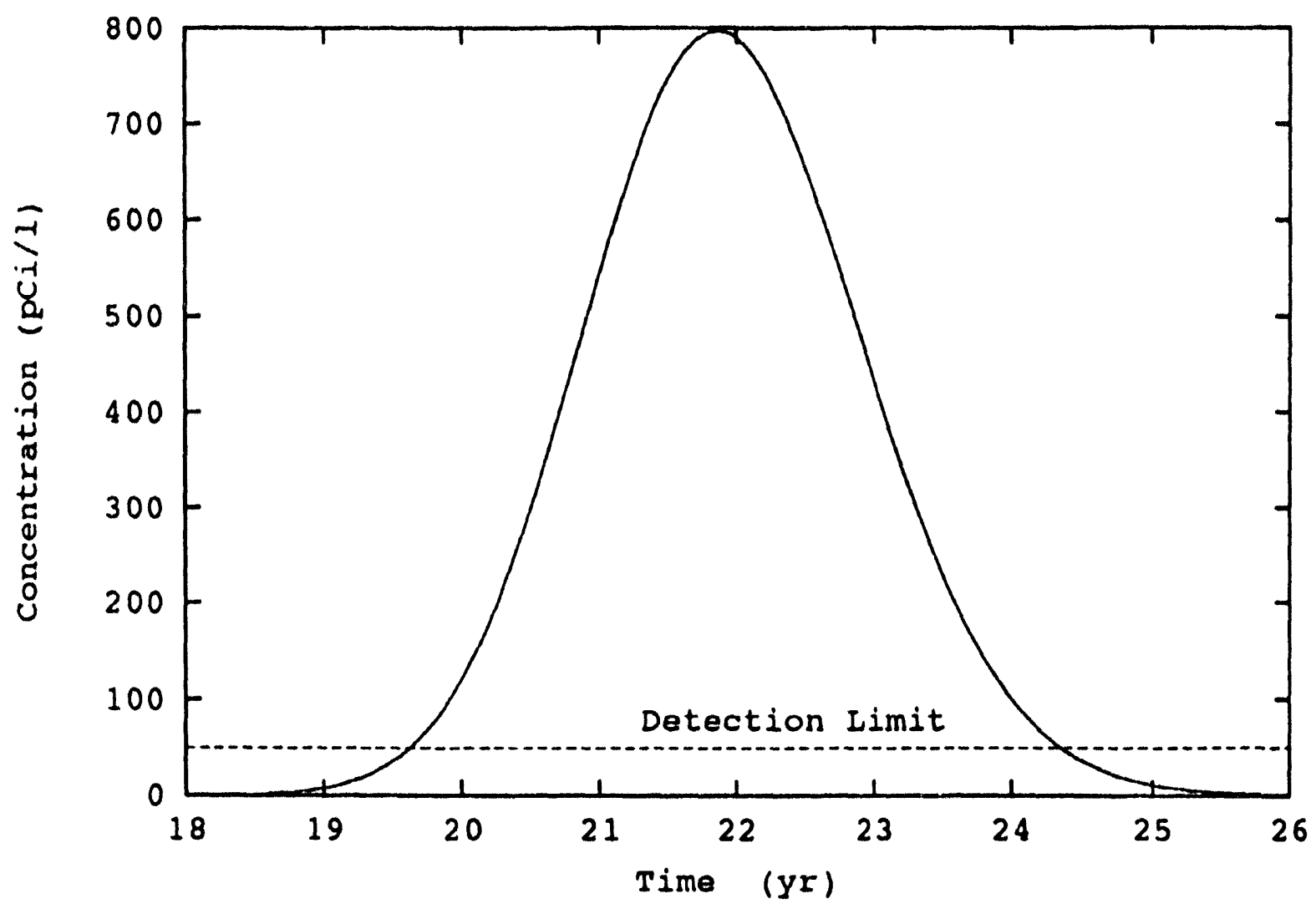

Figure 8. Breakthrough Curve for Tritium at $X=14.2 \mathrm{~km}$, the Approximate Distance to the Nearest Springs from ATCS. Detection limit shown is $50 \mathrm{pCi} / 1$ concentration, $M_{0}=1.41 \mathrm{Ci}$.

concentrations at the springs and Devil's Hole would be below $20,000 \mathrm{pCi} /$, and a 95 percent probability that concentrations would be less than $23,000 \mathrm{pCi} /$. The effect of dilution along the fault would likely reduce concentrations at the springs to below the Safe Drinking Water Act standard. These results indicate that detectable tritium from the ATCS tests might reach the nearest springs had remediation not taken place, provided dilution during flow along the fault reduced concentrations by less than 1.5 orders of magnitude.

Uncertainty in the three independent parameters $\phi b, a_{L}, a_{T}$ contributes to the uncertainty in $C_{\max }$. Note that this parameter is independent of velocity (see eq. 1). The relative contributions of the parameters to the variance of $C_{\max }$ can be determined simply by plotting the individual terms of eq. (5) as applied to eq. (1) (Figure 10). The uncertainty in the effective porosity-aquifer thickness product $(\phi b)$ dominates the variance, with uncertainty in longitudinal and transverse dispersivity contributions an order of magnitude lower, respectively.

Plume boundaries can be computed as before for above $20,000 \mathrm{pCi} /$ and above-detection limit concentrations. These calculations indicate that even if the ATCS site had not been remediated, the most probable extent of hazardous concentrations would not reach the Ash Meadows fault zone (Figure 11). As a result of dispersion, the elliptical body of contaminant 


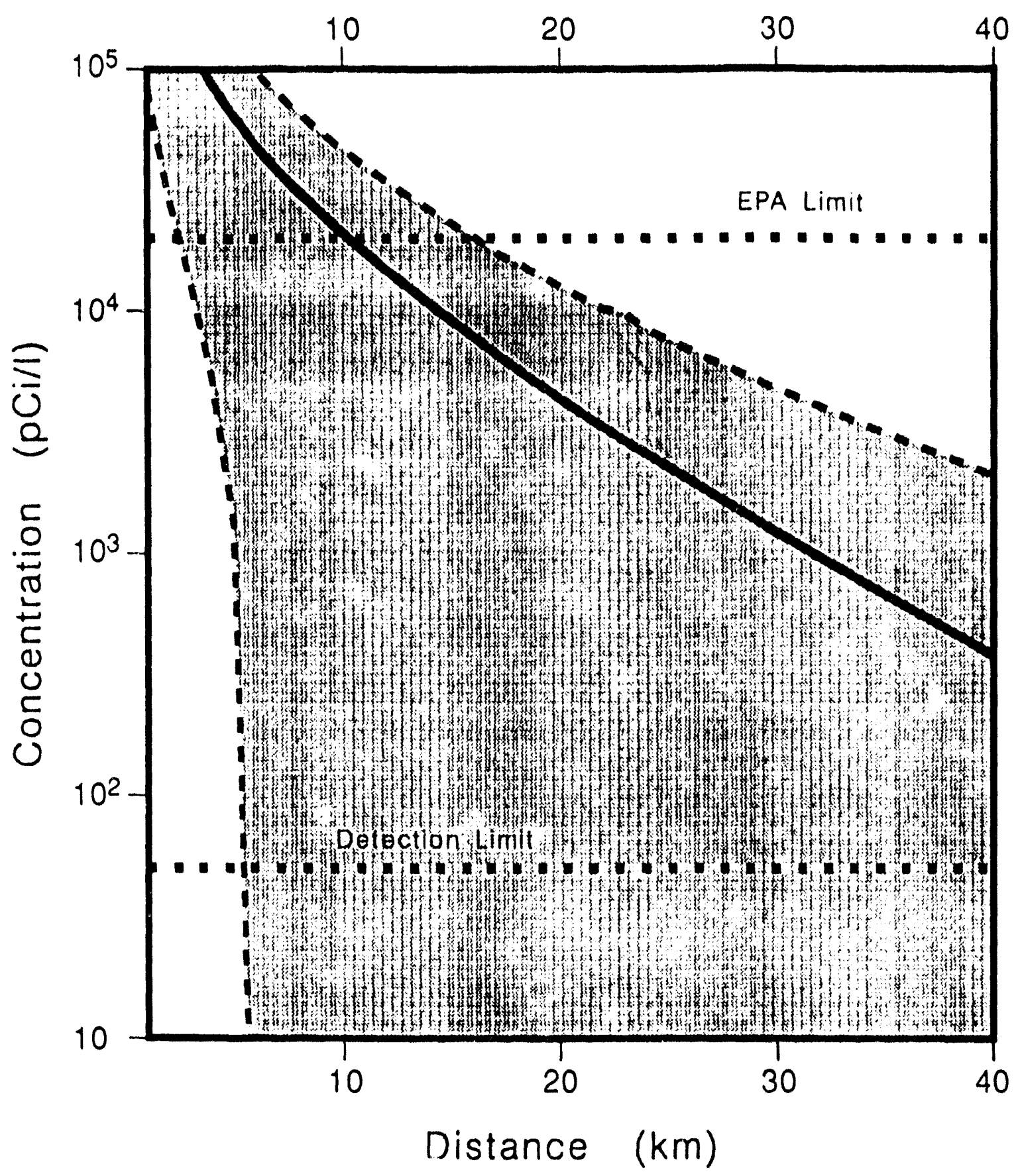

Figure 9. Computed Peak Concentrations vs Distance Downgradient from ATCS Using Inputs from Table 1 and $M_{o}=14.1 \mathrm{Ci}$ in eq. (1). Solid line shows expected value of $C_{m 2 x}, 95 \%$ confidence interval (2o) value shown by shaded region. 


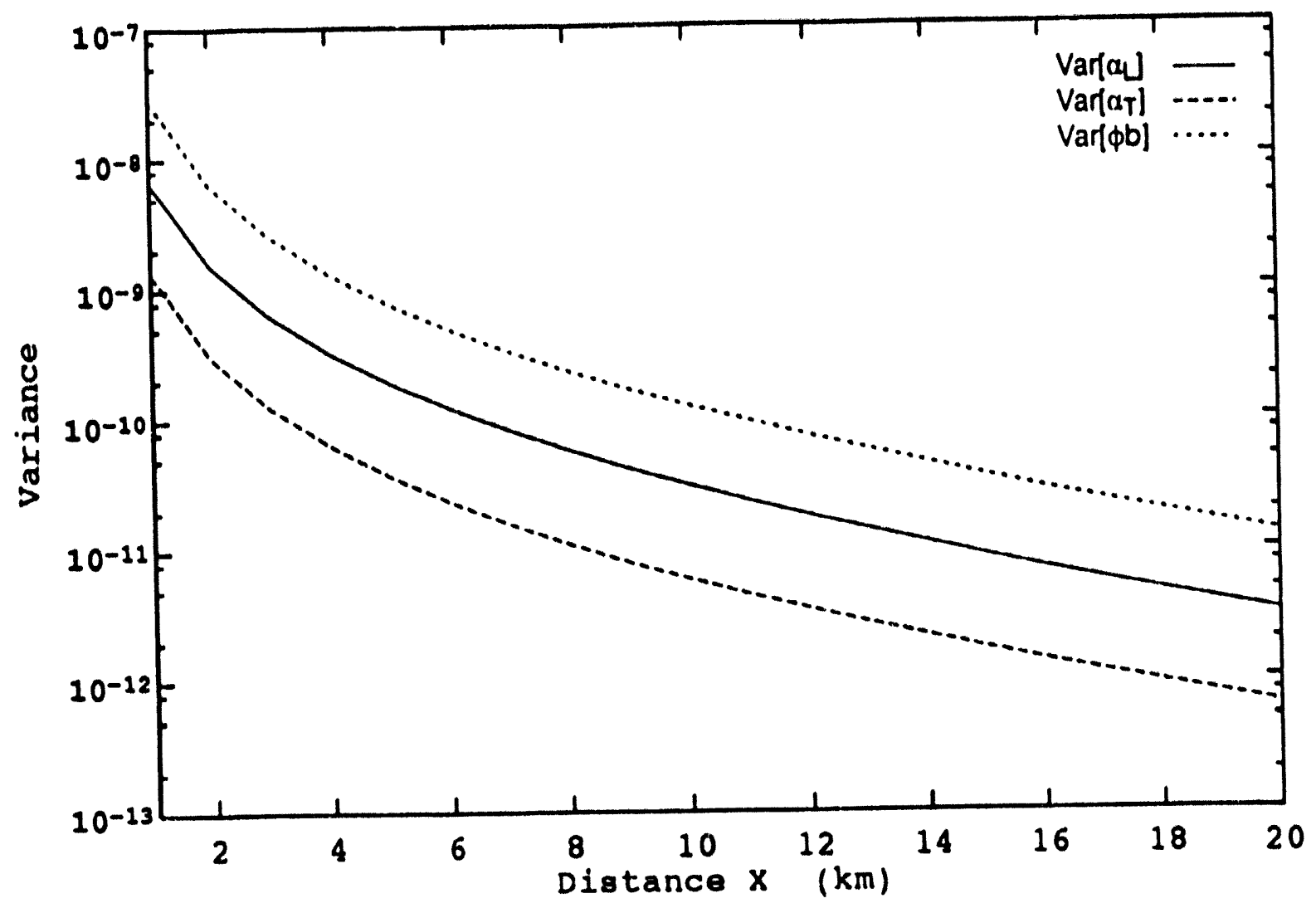

Figure 10. Contributions to Variance of $C_{\max }$ for $M_{0}=14.1 \mathrm{Ci}$.

grows during the early stages of transport (through the first five years), then shrinks owing to the combined effects of dispersion and radioactive decay. A contour enclosing the area expected to exceed $20,000 \mathrm{pCi} / \mathrm{l}$ (with 95 percent confidence) extends approximately $16 \mathrm{~km}$ from the ATCS. The 95 percent probability region extends much farther than the most probable plumes, as a result of uncertainty associated with the regional groundwater pore velocity. The extent of detectable tritium with time can be illustrated as before. Owing to the effects of dispersion, the elliptical contour of detectable concentration grows until it reaches the Ash Meadows fault (Figure 12) and would continue to expand until about 35 years (not shown). Ignoring the effects of dilution along the fault, detectable levels of tritium would be expected to arrive at Ash Meadows springs approximately 20 years after release at ATCS.

\section{CONCLUSIONS}

The goal of this study was to determine the risk that tritium left in the carbonate aquifer during tracer tests at ATCS might reach areas of potential public exposure. Lack of accessible documentation regarding the removal of radioactive tracers from the aquifer after the tests meant that the possibility of migration to downgradient springs or wells could not be ruled out with complete confidence. The analytic solutions employed above indicate that if the ATCS had 


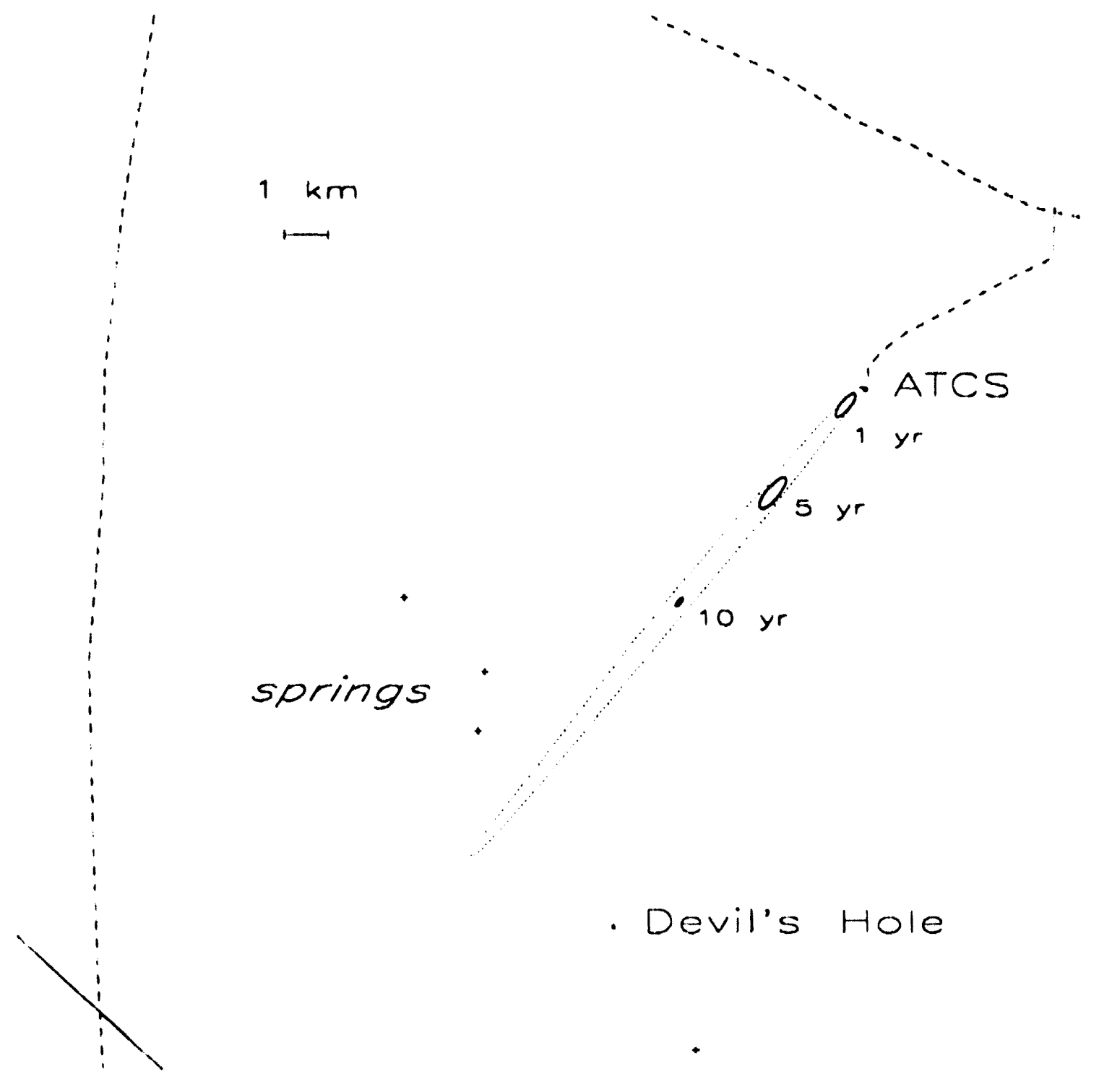

Figure 11. Outlines of Computed Plume Boundaries vs Time for the ATCS, given $M_{o}=14.1 \mathrm{Ci}$. Ellipses show the areas predicted to exceed $20,000 \mathrm{pCi} / \mathrm{I}$ tritium. Dotted line represents $95 \%$ confidence region for above $20,000 \mathrm{pCi} / 1$ concentrations. 


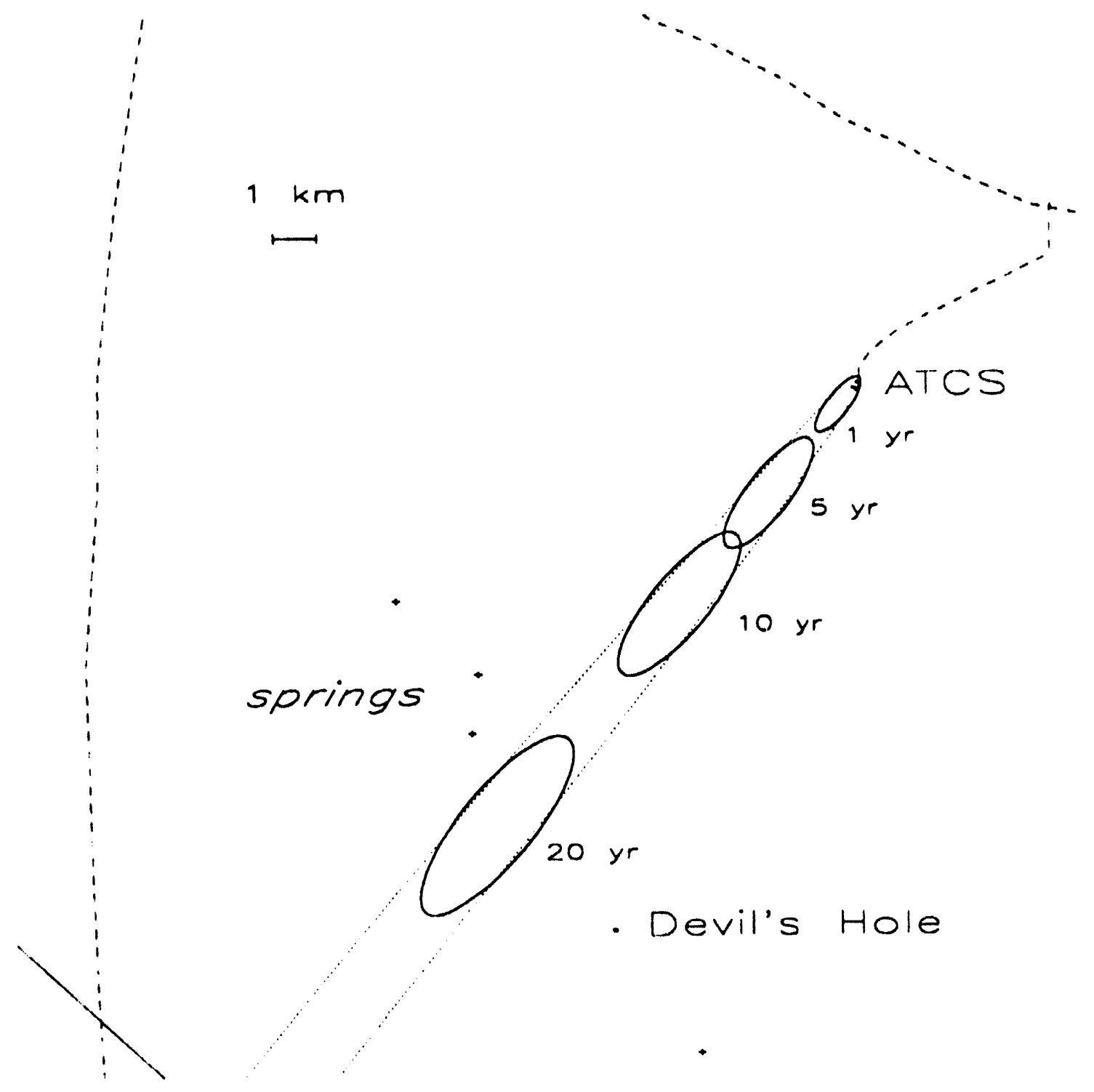

Figure 12. Outlines of Detectable Tritium vs Time for the ATCS Assuming $M_{o}=14.1 \mathrm{Ci}$. Contour of the $50 \mathrm{pCi} / 1$ concentration is shown, equivalent to levels of tritium in 1990 precipitation in the area. Dotted line represents $95 \%$ confidence region for concentrations exceeding $50 \mathrm{pCi} /$. 
not been remediated, a detectable tritium signal might be observable at Ash Meadows springs (Longstreet and School springs, and Devil's Hole) beginning 20 years after release. If remediation took place as verbally described, tritium from ATCS might still be detectable in Ash Meadows spring, but the possibility is very unlikely. In both cases maximum possible tritium concentrations at Ash Meadows springs would be near or below Safe Drinking Water Act standards. Only the 1971 tracer test was modeled in this study, transport from the 1975 test would be expected to yield nearly identical results, of course delayed by four years. Predicted downgradient tritium concentrations from the two tests would be additive, essentially increasing the likelihood of detectable tritium in Ash Meadows springs by a factor of two.

Should ATCS tritium have rear ied Ash Meadows springs, a small chance exists that it may be detected by the NTS off-site monitoring program. Since 1970, the EPA has conducted an off-site radiation monitoring program to detect releases from NTS activities. Included in this program is monitoring of tritium content of Ash Meadows springs and wells, including Fairbanks Spring and Crystal Pool. These springs lie relatively far from the point on the Ash Meadows fault directly downgradient from ATCS, and would be even more unlikely to exhibit clevated tritium from ATCS than Longstreet and School springs. Should any of :iese springs be found to have elevated tritium concentrations, ATCS rather than NTS should be regarded as the probable source.

Tracer studies such as those carried out at ATCS are an important method for understanding groundwater transport at the field scale. When managed properly, use of potentially hazardous tracers such as tritium is justified and greatly furthers the science of hydrology. Care appears to have been taken at ATCS to remove as much of the tracers as possible from the aquifer, minimizing the chances of post-test public exposure to the tracers. While this kind of remediation is now required by state and federal agencies, at the time of the ATCS testing it was a new concept, and the agencies responsible for developing ATCS are to be commended for the care they exercised. Unfortunately, recordkeeping of the remediation was insufficient by modern regulatory standards, making the current study necessary. As designed (i.e., including remediation) the studies at ATCS pose no risk to the public; if left unremediated, ATCS activities might be detectable at downgradient springs, but at most would barely exceed the Drinking Water standard for tritium. 


\section{REFERENCES}

Benjamin, J.R. and C.A. Cornell, 1970. Probability, Statistics, and Decision for Civil Engineers. p. 684, McGraw-Hill, New York.

Claassen, H.C. and E.H. Cordes, 1975. "Two-well recirculating tracer test in fractured carbonate rock, Nevada." Hydrological Sciences Bull., Vol. 20, No. 3.

De Josselin de Jong, G., 1958. "Longitudinal and transverse diffusion in granular deposits." Trans. Amer. Geophys. Union, Vol. 39, No. 1, p. 67.

Dudley, W.W., Jr. and J.D. Larson, 1976. "Effect of irrigation pumping on desert pupfish habitats in Ash Meadows, Nye County, Nevada." Professional Paper, Vol. 927, U.S. Geol. Survey, Washington, D.C.

Fetter, C.W., 1993. Contaminant Hydrogeology. p. 458, Macmillan, New York.

Fried, J.J. and M.A. Combarnous, 1971. "Dispersion in porous media." Advances in Hydrosci., Vol. 7, pp. 169-282.

Grove, D.B. and W.A. Beetem, 1971. "Porosity and dispersion calculation for fractured carbonate aquifer, using the 2-well tracer method." Water Resour. Res., Vol. 7, pp. 128-134.

Grove, D.B., 1971. "U.S. Geological Survey tracer study, Amargosa Desert, Nye County, Nevada, Part II: An analysis of the flow field of a discharging-recharging pair of wells." Open-File Rept. USGS-474-99, p. 56, U. S. Geol. Survey, Denver, CO.

Johnston, R.H., 1968. "U.S. Geological Survey tracer study, Amargosa Desert, Nye County, Nevada, Part I: Exploratory drilling, tracer well construction and testing, and preliminary findings." Open-File Rept. USGS-474-98, p. 64, U. S. Geol. Survey, Washington, D.C.

Leap, D.I., 1992. "Apparent relative retardation of tritium and bromide in dolomite." Ground Water, Vol. 30, pp. 549-558.

Leap, D.I. and P.M. Belmonte, 1992. "Influence of pore pressure on apparent dispersivity of a fissured dolomitic aquifer." Ground Water, Vol. 30, pp. 87-95.

Sauty, J.-P., 1980. "An analysis of hydrodispersive transfer in aquifers." Water Resour. Res., Vol. 16, pp. 145-158.

Walker, G.E. and T.E. Eakin, 1963. Geology and ground-water of the Amargosa Desert, Nevada-California. Ground-Water Resour. Reconn. Rpt. 14, Nevada Department of Conservation and Natural Resources, Carson City, NV, Pl. 2.

Winograd, I.J. and W. Thordarson, 1975. "Hydrogeologic and hydrochemical framework, south-central Great Basin, Nevada-California, with special reference to the Nevada Test Site." USGS Prof. Paper 712-C, p. 127. 


\section{APPENDIX}

\section{Records of Site Remediation}




\section{RECORDS OF SITE REMEDIATION}

As discussed in the text, records of the removal of radioactive tracers from the carbonate aquifer at Amargosa Tracer Calibration Site (ATCS) are not readily obtainable. Should these records ever be needed, a summary of what is currently known about them is provided below.

The scientists responsible for the three tracer tests described the removal during telephone conversations (Claassen, personal comm., 1993; Leap, personal comm., 1993). In each case, recirculation was stopped at the end of the tracer test, and pumping continued for approximately 30 days, with discharge directed into a surface pond. Samples were taken during removal, and at the end of pumping concentrations were near detection limits $(500$ to $1,300 \mathrm{pCi} / 1$ or 150 to 400 TU) using scintillation counters. The 1971 test using tritium was supervised by Hans Claassen of the U.S. Geological Survey (USGS). Claassen also played a major role in the second test at ATCS using sulfur-35 in 1973. By 1975, responsibility for the project (and all pertinent records) had been transferred to Daryl Leap, then a new employee at the USGS, now a professor at Purdue University. Leap supervised the 1975 tritium-Br test. Most of the records of the tests were left at the USGS by Leap, and are presumably somewhere in their archives in Denver. A cursory search for the records by Claassen in 1993 was unsuccessful.

The most likely location of accurate records of the remediation are with the agency that licensed the use of the radioactive tracers. A description of the final cleanup of the site would have been delivered to the licensing agency at the end of each test. A radiological safety license was obtained by USGS-Denver for the 1971 test, and another license for the sulfur and 1975 tritium tests. The latter license was obtained by Bill Smith, acting as health and safety coordinator for the Geology Division, USGS-Denver (now retired). The AEC (now NRC) would have been responsible for licensing tests in Nevada before 1972. Their Region 4 office (Arlington, Texas) would house records of licenses obtained by USGS-Denver. NRC's records are filed by docket number only, making a search very difficult without that number. The number would presumably be given in correspondence between the USGS and AEC; Leap and Claassen could find no such correspondence in their files. Nevada became an "agreement state" in 1972, and the state would have licensed any radionuclide releases from that time on. The Radiological Health Division of the Nevada Health Department was unable to locate records of the 1975 tritium test.

In summary, records of the remediation of ATCS were filed with the licensing agencies (to the best recollection of Claassen and Leap). These records were not found during preliminary inquiries for this study. The most likely location of these records are at NRC Region 4. The verbal description of remediation given by Claassen and Leap together with the analyses presented here should be a sufficient assurance that ATCS presents no public hazard. Further searching for the records is likely to be quite time consuming and, therefore, is not recommended unless a very strong need for official records arises. 


\section{DISTRIBUTION}

\section{U.S. Department of Energy}

Gylan Allen

Test Operations Division

Nevada Operations Office

U.S. Dept. of Energy

P.O. Box 98518

Las Vegas, NV 89193-8518

Doug Duncan

Hydrology Program Manager

Office of Environmental Restoration \& Waste

Management

Nevada Operations Office

U.S. Dept. of Energy

P.O. Box 98518

Las Vegas, NV 89193-8518

Don Elle, Director

Environment Protection Division

Nevada Operations Office

U.S. Dept. of Energy

P.O. Box 98518

Las Vegas, NV 89193-8518

Joseph N. Fiore, Acting Asst. Mgr.

Office of Environmental Restoration \& Waste

Management

Nevada Operations Office

U.S. Dept. of Energy

P.O. Box 98518

Las Vegas, NV 89193-8518

Joseph H. Kitchen

Technology and Program Management Division Nevada Operations Office

U.S. Dept. of Energy

P.O. Box 98518

Las Vegas, NV 89193-8518

Steve Lawrence

Environmental Restoration Division

Nevada Operations Office

U.S. Dept. of Energy

P.O. Box 98518

Las Vegas, NV 89193-8518
John S. Ledbetter

Contracts Division

Nevada Operations Office

U.S. Dept. of Energy

P.O. Box 98518, MS 505

Las Vegas, NV 89193-8518

Steve Leedom

Test Operations Division

Nevada Operations Office

U.S. Dept. of Energy

P.O. Box 98518

Las Vegas, NV 89193-8518

Steve Mellington, Director

Environmental Restoration Division

Nevada Operations Office

U.S. Dept. of Energy

P.O. Box 98518

Las Vegas, NV 89193-8518

Technical Information Resource Center

Nevada Operations Office

U.S. Dept. of Energy

P.O. Box 98518

Las Vegas, NV 89193-8518

Richard Pearl

Environmental Protection Division

Nevada Operations Office

U.S. Dept. of Energy

P.O. Box 98518

Las Vegas, NV 89193-8518

\section{U.S. Department of Defense}

David Bedsun

Defense Nuclear Agency

U.S. Department of Defense

P.O. Box 98539

Las Vegas, NV 89193-8539

\section{Lawrence Livermore National Laboratory}

Lee Davisson

Nuclear Chemistry Division

Lawrence Livermore National Laboratory

P.O. Box 808, MS L237

Livermore, CA 94550 
Greg Nimz

Lawrence Livermore National Laboratory P.O. Box 808, MS L233

Livermore, CA 94550

\section{Los Alamos National Laboratory}

Joe Thompson

Los Alamos National Laboratory

INC-11, MS J514

P.O. Box 1663

Los Alamos, NM 87545

\section{U.S. Geological Survey}

Virginia Glanzman

U.S. Geological Survey

Box 2506, MS 913

Denver Federal Center

Denver, CO 80225

Randy Laczniak

U.S. Geological Survey

Water Resources Division

6770 S. Paradise Rd.

Las Vegas, NV 89119

Paul Orkild

U.S. Geological Survey

Box 2506, MS 913

Denver Federal Center

Denver, CO 80225

Doug Trudeau

U.S. Geological Survey

Water Resources Division

6770 S. Paradise Rd.

Las Vegas, NV 89119

Desert Research Institute

Roger Jacobson

Desert Research Institute

Water Resources Center

P.O. Box 19040

Las Vegas, NV 89132-0040
Marjory Jones

Desert Research Institute

Water Resources Center

P.O. Box 60220

Reno, NV 89506-0220

Paul Seaber

Desert Research Institute

Water Resources Center

P.O. Box 19040

Las Vegas, NV 89132-0040

Reynolds Electrical \& Engineering Co.

Martha DeMarre

Chief, Document Research Section

Health Protection Dept.

Reynolds Electrical \& Engineering Co.

P.O. Box 98521

Las Vegas, NV 89193-8521

Brian Dozjer

Reynolds Electrical \& Engineering Co.

2501 Wyandotte

Mercury, NV 89102

\section{LIBRARIES}

Archives

Getchell Library

University of Nevada, Reno

Beverly Carter

MacKay School of Mines Library

University of Nevada, Reno

Stead Library

Desert Research Institute

Reno, Nevada

Southern Nevada Science Center

Water Resources Center, Library

P.O. Box 19040

Las Vegas, NV 89132-0040

Document Section, Library

University of Nevada, Las Vegas

4505 Maryland Parkway

Las Vegas, NV 89154 
Annie Kelley

State Documents Department

Nevada State Library

Capitol Complex

Carson City, NV 89710

Water Resources Research Archives University of California

Room 40, North Gate Hall

Berkeley, CA 94720
International Technology Corp.

Rick Waddell

Geotrans

clo IT

4330 Valley View

Suite 112

MS-439

Las Vegas, NV 89103

Joe Yeasted

International Technology Corp.

Southern Nevada Science Center

P.O. Box 19040

Las Vegas, NV 89132-0040 

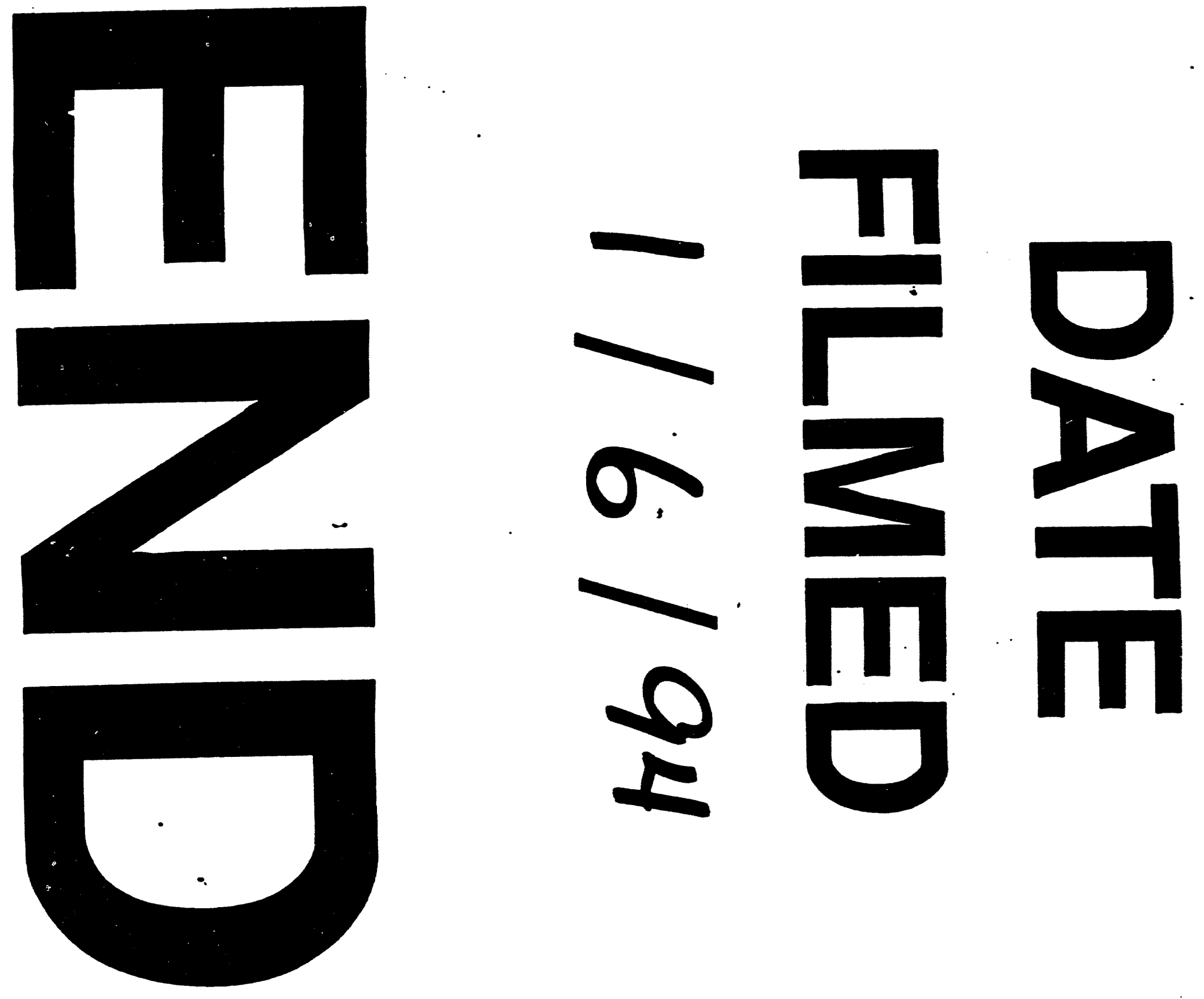
